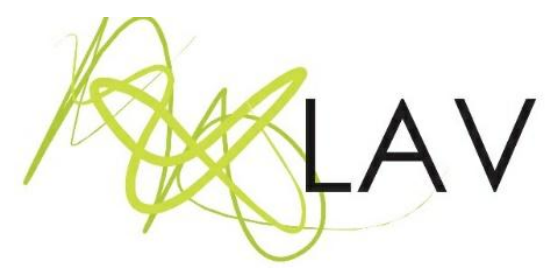

\title{
Moda artesanal: explorando uma cultura regional brasileira por técnicas e saberes tradicionais
}

\author{
Artisanal fashion: exploring a Brazilian regional culture through traditional techniques \\ and knowledge
}

Cássia Cristina Dominguez Santana ${ }^{i}$
Universidade Federal de Minas Gerais - UFMG

Soraya Aparecida Alvares Coppolaii Universidade Federal de Minas Gerais - UFMG

\begin{abstract}
Resumo
O fator cultural, como artifício de diferenciação, gera uma crescente demanda de produtos que expressam características de determinadas regiões. O Nordeste do Brasil conta com uma vasta riqueza cultural que valoriza o trabalho artesanal. Atualmente, a identidade cultural de diversas regiões tem sido valorizada no universo da moda. Designers e artesãos trabalham produtos e cenários nordestinos em suas criações. Ao encontro disso, este artigo aborda o desenvolvimento de têxteis artesanais utilizando a técnica de reutilização têxtil ou upcycling para o desenvolvimento de uma coleção de bolsas inspirada na riqueza cultural do Nordeste brasileiro. A pesquisa baseia-se em saberes tradicionais, nas inspirações da cultura têxtil nordestina e no tecido cultural de chita. As peças finais refletem uma visão consciente do momento atual e o elo entre design e artesanato, passado e presente, sustentabilidade e qualidade, com valor simbólico ligado às raízes culturais de um povo.
\end{abstract}

Palavras-chave: arte têxtil, tecelagem, artesanato, Nordeste do Brasil, identidade cultural.

\section{Abstract}

The cultural factor, as a differentiation device, generates an increasing demand for products that express characteristics of certain regions. Northeast Brazil has a vast cultural wealth that values artisanal work. Currently, the cultural identity of several regions has been valued in the fashion universe. Designers and artisans manipulate products and scenarios from the Northeast in their creations. Thereby, this article discusses the development of handmade textiles using the technique of textile reuse or upcycling for the development of a collection of bags inspired by the cultural wealth of Northeast Brazil. The research is based on traditional knowledge, the inspirations of the Northeast textile culture and the cultural fabric of chintz. The final pieces reflect an aware view of the current moment and the link between design and crafts, past and present, sustainability and quality, with symbolic value linked to the cultural roots of people.

Keywords: textile art, weaving, handicrafts, Northeastern Brazil, cultural identity. 


\section{Introdução}

O Brasil é reconhecido por sua diversidade cultural marcante, decorrente das colonizações e migrações que ocorreram ao longo de sua história. Essa riqueza proporciona que cada região do país apresente características e tradições próprias. Dessa forma, o crescente interesse pelo resgate de técnicas e saberes tradicionais das culturas locais contribui fortemente para adicionar valor cultural aos produtos artesanais criados em cada região. Esse valor gera distinção nos produtos artesanais e colabora para uma vantagem competitiva no mercado consumidor, uma vez que os produtos se tornam únicos.

O Nordeste do país conta com uma produção artesanal rica e variada que é perpetuada pela população. Trata-se de um artesanato marcado por influências de diferentes povos, variando, consequentemente, as técnicas e peças de um estado para outro. $\mathrm{O}$ artesanato com trançados e rendas nordestinas possui forte influência indígena e se caracterizam como saberes transmitidos de geração em geração para a criação de artigos para cama e mesa, peças de decoração, acessórios, vestuário, entre outros.

A tecelagem manual, considerada um setor do artesanato, é uma arte que acompanha o desenvolvimento do ser humano desde as civilizações da Antiguidade. A tecelagem artesanal, passada de geração a geração, permite a construção de tecidos em crochê, tricô e tecidos produzidos em teares artesanais de pedais, pente liço, de pregos ou pinos que variam de tamanhos. Na maior parte, essa tecelagem é feita com fios de algodão, uma das fibras naturais mais antigas cultivadas pelo homem. Por ser uma fibra que suporta grande tensão, o algodão é usado principalmente na urdidura dos tecidos. E é essa fibra, tão antiga, que dá origem ao tecido de chita - tecido de algodão estampado originário do Oriente que chegou ao Brasil em 1498, e hoje faz parte da cultura brasileira (PEZZOLO, 2009).

A moda e o design estão interligados e buscam desenvolver produtos que não somente satisfaçam o consumidor final, mas, que supram necessidades da sociedade em geral, por meio da preocupação com questões como a durabilidade do produto - para que haja um rápido descarte e de forma inadequada, trazendo prejuízo ao meio ambiente -, e com a escolha adequada do tipo de material, ou seja, que ofereça conforto ao cliente e também solucione demandas têxteis.

Dessa forma, o design está sendo inserido no artesanato a partir da observação e aplicação dos princípios básicos de design, minimizando possíveis carências e garantindo um produto de sucesso. Ele tem sido aplicado a grupos de artesanato de diversas regiões 
como forma de promover e potencializar os produtos artesanais, pois todo o artesanato demanda técnica, criatividade, habilidade e possui valor simbólico como identidade cultural.

A moda tem ajudado no resgate da identidade cultural do artesanato. Designers e artesãos têm valorizado o cenário nordestino em suas criações. Um exemplo disso é o caso da estilista alagoana Martha Medeiros, que com sua marca resgata o luxo das tramas e bordados feitos à mão. Pelas mãos da estilista, a moda artesanal ganhou status. Seu trabalho contribui para a expansão turística e identidade cultural do artesanato, pois as suas campanhas trazem como cenário as belezas do Nordeste.

Segundo a ABIT (2019), o Brasil é a maior Cadeia Têxtil completa do Ocidente, sendo, em 2019, responsável pela produção de 8,9 bilhões de peças têxteis e 1,2 milhão de toneladas de produção têxtil. A moda brasileira está entre as cinco maiores Semanas de Moda do mundo (ABIT, 2019; TEX BRASIL, 2019). Assim, com o crescente consumo no setor da moda, a produção em massa traz sérios prejuízos para o planeta, dentre os quais está o grande volume de resíduos têxteis. De maneira inevitável cada peça produzida gera retalhos que comumente são descartados no lixo. Porém, um conceito novo que vem ganhando espaço na moda é o upcyling ${ }^{1}$ (reaproveitamento de retalhos, sobras e peças têxteis), que de acordo com Lucietti et al (2018) é uma técnica que nasceu como forma de evitar o descarte indevido de materiais ainda úteis, o que reduz o consumo de novas matérias-primas durante a criação de novos produtos.

Considerando o exposto, este artigo explora a pesquisa desenvolvida para o Trabalho de Conclusão de Curso de Design de Moda da Escola de Belas Artes da Universidade Federal de Minas Gerais. Com base em pesquisas bibliográficas e iconográficas sobre design, artesanato, identidade cultural, tecelagem manual e sustentabilidade, foram desenvolvidos tecidos em tear manual de pregos, utilizando a técnica sustentável de reaproveitamento têxtil, bem como dialogando com a identidade cultural da região Nordeste do Brasil, em especial com o artesanato com rendas e trançados e aos tecidos de chita com sua característica marcante de cores e estampas que lembram a exuberância da flora brasileira.

Com padronagens distintas e técnicas de tecelagem variadas, foram desenvolvidos tecidos com retalhos e sobras de têxteis de algodão com cores, tramas e texturas diferentes. Os têxteis deram base para o desenvolvimento de uma coleção composta por doze bolsas artesanais, das quais foram confeccionadas seis peças, com

\footnotetext{
1 Upcycling é o termo utilizado para sinalizar a reutilização de um material na criação de um novo produto original. Na moda está relacionado ao reaproveitamento de retalhos e peças de roupas já sem utilização.
} 
valor cultural inserido, remetendo às técnicas de saberes tradicionais dos povos colonizadores e nativos e às cores do artesanato da região Nordeste. Os produtos finais pretenderam satisfazer conceitos de design, artesanato e sustentabilidade por meio do desenvolvimento de produtos de moda com valor simbólico cultural.

A presente pesquisa se fundamenta no envolvimento dos antepassados da pesquisadora com o artesanato e saberes tradicionais, junto do conhecimento adquirido no curso de Design de Moda e inspirações na cultura têxtil nordestina com os tecidos estampados de chita, que levaram à construção de têxteis e produtos autorais. O passado adentra o presente inspirando o desenvolvimento de têxteis artesanais trabalhados em teares de pregos, seguindo a cadência das tecelãs, rendeiras e artesãs de várias regiões da Bahia.

A essas inspirações somam-se a identidade cultural nordestina, a representação da tecelagem artesanal do Nordeste - principalmente da Bahia -, a alegria das cores, o uso do tecido cultural de algodão, a chita e a preocupação com a sustentabilidade. Assim, com o aproveitamento de retalhos, peças e tecidos que não teriam mais uso, a pesquisa utilizou a técnica de reutilização têxtil (upcycling) e a valorização de técnicas de saberes tradicionais e culturais, como o artesanato, com o trabalho de tessitura em tear de pregos, para construir novos tecidos a partir dos quais nasceu uma coleção de bolsas inspiradas na riqueza cultural do Nordeste brasileiro.

A coleção de bolsas foi dividida em quatro famílias, pensadas a partir do conjunto de inspirações juntamente às obras de dois escritores nordestinos, um compositor e um poeta. As obras exaltam a cultura nordestina e remetem a pontos específicos da pesquisa como os trançados, rendas, flores da chita e tear. Para cada família foi desenvolvido um design têxtil específico.

Dessa forma, foram criados artefatos de moda com base na reflexão acerca das questões ambientais, na preocupação com a preservação do planeta, do descarte e uso correto dos resíduos têxteis, na valorização da identidade cultural dos povos, no incentivo de artesãos e designers para construção de produtos mais sustentáveis, com qualidade e valor identitário.

\section{Inter-relação da Arte, Artesanato e Design}

A arte está relacionada a uma ideia de expressão. Segundo Azevedo Júnior (2007), a arte é uma das primeiras manifestações da humanidade como forma do ser 
humano marcar sua presença criando objetos e formas (pintura nas cavernas, templos religiosos, roupas, quadros, filmes, etc.) que representam sua vivência no mundo, comunicando e expressando suas ideias, sentimentos e sensações para os outros. Sendo assim, o artista usa sua técnica e seu conhecimento especialmente para se expressar.

Hatta, Santos e Costa (2013) acreditam que a arte é o conhecimento mais profundo e verdadeiro da essência do mundo. Ela concebe que o conhecimento estético é a forma de assimilar o sensível e trazer a comunicação da beleza, no qual o espectador é responsável pela obra e por sua definição. A arte, portanto, tem o poder de despertar, em seu observador, sentimentos variados.

O artesanato, por sua vez, está relacionado ao sentido prático, mas também a uma ideia de expressão. O artesão usa sua técnica, seu conhecimento, vivências e ideias para criar objetos utilitários com significados culturais visando à comercialização. Para Figueiredo e Marquesan (2014, p. 131), a arte e o artesanato transmitem significados diferentes com linguagens similares, "ambos tendem a se valer de processos, materiais e técnicas bastante semelhantes em termos de forma e conteúdo".

A arte, aparentemente dotada de um potencial contemplativo explícito, decorrente de sua não utilidade, se apresenta à experiência da percepção como um exercício profundo de alteridade. Já o artesanato, por ser tradicional e preponderantemente prático e útil, se apresenta à percepção como um processo organizado em torno da experiência material (FIGUEIREDO; MARQUESAN, 2014, p. 132).

As ponderações sobre o que é arte e artesanato podem variar com as diferenças culturais. Os significados dos objetos dependem da cultura que estão inseridos, pois, objetos vistos como funcionais em determinada cultura podem ser apreciados como arte por outros povos. Para os autores, se o artesanato não pode se ajustar nas normas da arte ele se configura como uma "expressão peculiar do espírito humano" e se enquadra como uma forma de arte distinta, "ligada à estética oriunda da cultura popular". Sendo assim, artesanato pode ser considerado como uma configuração de arte (Ibidem, p. 5).

Para França (2005, p. 4), a produção artesanal é caracterizada pelo "domínio do artesão em todas as fases do processo produtivo", que inclui a obtenção de matériaprima, o domínio de técnicas de produção, o processo de trabalho e a comercialização do produto. $\mathrm{O}$ artesanato:

Compreende toda a produção resultante da transformação de matérias-primas, com predominância manual, por indivíduo que detenha o domínio integral de uma ou mais técnicas, aliando criatividade, habilidade e valor cultural (possui valor simbólico e 
identidade cultural), podendo no processo de sua atividade ocorrer o auxílio limitado de máquinas, ferramentas, artefatos e utensílios (BRASIL, 2012, p. 12).

De acordo com a Base conceitual do artesanato brasileiro, obra publicada pelo Ministério do Desenvolvimento, Indústria e Comércio Exterior (MDIC) (Ibidem, p. 12), no artesanato, mesmo que as obras sejam criadas com instrumentos e máquinas, é a destreza manual do homem que dará uma característica própria e criativa ao objeto, "refletindo a personalidade do artesão e a relação deste com o contexto sociocultural do qual emerge". Explica ainda que a matéria-prima para o artesanato pode ser utilizada tanto no seu estado natural como depois de processada ou mesmo decorrente de processos de reciclagem ou reutilização, como é o caso desta pesquisa, que reutiliza a matéria-prima, no caso, tecidos de algodão.

Figueiredo e Marquesan (2014) citam o design como um ponto intermediário entre a arte e o artesanato:

[...], o design coloca-se no ponto intermediário entre arte e artesanato; aproximando-se tanto da arte - no que diz respeito à ênfase sobre a autoria como critério para demarcar o valor dos objetos para determinado grupo social - quanto do artesanato enquanto modo de conceber objetos úteis, funcionais à consecução de algum objetivo ou necessidade surgida do cotidiano das pessoas (FIGUEIREDO; MARQUESAN, 2014, p. 133).

Conforme explica Montemezzo (2003, p. 17), "o design envolve um conjunto de interações entre designer, processos produtivos, mercado consumidor e produto". Um designer visa desenvolver produtos inovadores com características que sejam valorizadas pelos consumidores. Assim, no processo de desenvolvimento de um projeto é primordial analisar as metodologias e princípios do design, pois o projeto é tanto um processo criativo como um processo de solução de problemas - necessidades sociais, ambientais, humanas -, e o profissional deve propor soluções criativas e eficazes de forma a minimizar possíveis carências.

Segundo Figueiredo e Marquesan (2014), a linha de pensamento que era difundida pela escola Bauhaus ${ }^{2}$, com o design funcionalista, unia os conceitos de arte e artesanato com o objetivo de criar uma nova ideia estética e utilitária tanto para ambientes como objetos. O valor do artesanato é exaltado em um manifesto de 1919, produzido pelo arquiteto fundador da escola de Bahaus, Walter Gropius, como mostra o trecho abaixo:

\footnotetext{
2 Bauhaus foi a primeira escola de design do mundo. Fundada por Walter Gropius em 12 de Abril de 1919 na Alemanha.
} 
Arquitetos, escultores, pintores, todos devemos retornar ao artesanato, pois não existe 'arte por profissão'! Não existe nenhuma diferença essencial entre o artista e o artesão. O artista é uma elevação do artesão. A graça divina, em raros momentos de luz que estão além de sua vontade, inconscientemente faz florescer arte da obra de sua mão, entretanto, a base do 'saber fazer' é indispensável para todo artista. Aí se encontra a fonte primordial da criação artística. [...]. Formemos, portanto, uma nova corporação de artesãos, sem a presunção elitista que pretendia criar um muro de orgulho entre artesãos e artistas! (GROPIUS, 1919, s/p) ${ }^{3}$

Benz e Lessa (2016, p. 2) afirmam que atualmente se recorre ao design como "uma ferramenta para potencializar econômica e socialmente grupos de artesanato e a região que se localizam". Já para Nunes (2011), o conceito e a prática de design estão historicamente ligados ao fazer artesanal. O design surgiu vinculado aos processos produtivos tradicionais como o artesanato e também aos processos produtivos emergentes - a indústria. Porém, o design assumiu uma posição contraposta ao artesanato devido à "carência de análise teórica da prática do design" (NUNES, 2011, p. 12). Dessa forma, criou-se uma distinção prática entre produção em série e produção manual.

\section{Cultura regional, artesanato e moda}

Kashimoto, Marinho e Russeff (2002, p. 35) definem cultura como "o conjunto de soluções originais que um grupo de seres humanos inventa, a fim de se adaptar a seu meio ambiente natural e social". Sendo assim, a cultura abrange vários aspectos da vida como, costumes, conhecimentos, religião, valores, língua, comportamento social, político e econômico, entre outros.

Sobre a identidade cultural de uma região, Hall (2006) esclarece a questão do hibridismo - fusão de diferentes tradições culturais -, que produz novas culturas de forma criativa e também espelhadas no passado. De acordo com o autor, a globalização contribuiu para a ascensão acerca das identidades locais e regionais, pois ocorreram migrações de povos com deslocamentos entre as identidades culturais, criando um hibridismo de culturas. Hall (2006) afirma que "no mundo moderno, as culturas nacionais em que nascemos se constituem em uma das principais fontes de identidade cultural" (HALL, 2006, p. 47).

3 Disponível em: <https://www.goethe.de/ins/br/pt/kul/fok/bau/21394277.html>. Acesso em: 4 dez. 2019. 
A cultura regional constitui-se da união de manifestações culturais de uma determinada região. Sendo assim, está diretamente ligada à noção de identidade local, que é formada a partir da junção de manifestações culturais. De acordo com Pichler e Mello (2012), a identidade cultural, juntamente ao design, possibilita a mistura de diferentes elementos regionais e favorece o desenvolvimento de produtos ligados às raízes culturais dos consumidores, gerando um apelo com valor emocional.

Portanto, a valorização da cultura popular contribui para que a sociedade fortaleça a individuação e a autoestima diante do Outro, numa busca de desenvolvimento originário de sua própria criatividade e conforme os seus valores, porque é por intermédio da cultura que o indivíduo e a sociedade interagem com o mundo à sua volta (KASHIMOTO; MARINHO; RUSSEFF, 2002, p. 36).

Segundo Nogueira et al (2014, p. 4), as pessoas compram não apenas pela função dos produtos, mas também pelo valor simbólico, ou seja, conforme o seu significado expresso dentro da sociedade. Para os autores, o valor simbólico agrega-se ao valor funcional de produtos de consumo. Assim, "o consumo simbólico pode ser aliado à construção da identidade não apenas do indivíduo, mas de sua sociedade".

O crescente interesse por resgatar técnicas e saberes tradicionais das culturas locais contribui fortemente para adicionar valor simbólico cultural aos produtos artesanais criados em cada região. Esse valor gera distinção nos produtos artesanais e colabora para uma vantagem competitiva no mercado consumidor, uma vez que os produtos se tornam únicos. Para Figueiredo e Marquesan (2014, p. 129), "a produção ou a busca de objetos artesanais é sempre algo consciente que expressa uma forma de dissidência em relação aos padrões impostos e reproduzidos pelo sistema capitalista". Assim, faz-se necessária uma ênfase maior nessa representatividade cultural que colabora para o desenvolvimento econômico regional.

A moda tem resgatado a identidade cultural do artesanato. Designers e artesãos têm valorizado cenários regionais em suas criações, como no caso da estilista carioca, Isabela Capeto, que apresentou a coleção inverno/2017 com forte apelo para o trabalho artesanal da região do Cariri, no Ceará, e o artesão cearense e designer de joias, Francisco Antônio Rabelo, que idealiza joias a partir de técnicas de produção artesanal inspiradas em artigos do sertão.

Outra estilista que tem valorizado riquezas regionais é a alagoana, Martha Medeiros. As rendas utilizadas em suas peças são feitas por mãos de várias artesãs nordestinas. Para elaborar suas coleções, a estilista se inspira em suas memórias afetivas 
fincadas no sertão brasileiro, chegando a dedicar-se por mais de quatro anos na criação de uma coleção, a exemplo da coleção Sertões.

De acordo com Botelho (2016, s/p) ${ }^{4}$, "A moda é artesanal. Requer desenho, modelagem, corte, costura, bordado, aplicações, pinturas...". Segundo a jornalista, a parceria entre artesãos e designers tem sido um sucesso, pois a valorização do regionalismo e das tradições sempre rende frutos nas passarelas de todo o mundo.

O uso do elemento cultural, como forma de distinção, causa um aumento na demanda de produtos com características de determinadas regiões. No artesanato brasileiro, encontram-se significados de um legado artístico. O Nordeste do país conta com uma vasta produção artesanal que é perpetuada pela população. Dessa forma, pode-se concluir que "o uso do artesanato como objeto de consumo aliado ao design têxtil é essencial para a valorização e difusão da cultura popular no nordeste" (LIMA et al., 2013, p. 4).

\section{Por falar em Nordeste... trançados, rendas e tecelagem artesanal}

Uma das manifestações culturais mais ricas do Nordeste do Brasil é o artesanato. É interessante observar que grande parte das matérias-primas utilizadas é extraída da própria fauna e flora nativas da região, o que, além de valorizar cada local também se torna um atrativo turístico para a região, movimentando a renda e sustentando famílias. Os artesãos do Nordeste unem seu talento à herança cultural das gerações anteriores para representar seus estados e garantir sua subsistência.

Algumas modalidades artesanais no país são centenárias. Cerâmica, cestaria e trançado são de tradição indígena. Algumas são técnicas da Antiguidade, disseminadas na Idade Média por e para nobres, aristocratas e eclesiásticos. O trabalho em couro remete aos antigos ofícios tradicionais europeus. Rendas foram trazidas pelos europeus a partir do século XVII, e os bordados transmitidos em escolas de educadoras religiosas até meados do século XX (ROSSI, 2015, p. 244).

Muitos trabalhos artesanais são comuns a todos os estados do Nordeste, como o artesanato com fuxico ${ }^{5}$, o trabalho com trançados de palha e diversos tipos de rendas. Vainsencher (2007) aborda o artesanato específico em cada estado da região Nordeste.

\footnotetext{
${ }^{4}$ Disponível em: <http://www.revistacontinente.com.br/edicoes/183/moda--criacoes-artesanais-eautossustentaveis>. Acesso em: 4 dez. 2019.

5 Fuxico é uma técnica artesanal com aproveitamento de retalhos de tecidos cortados em formato circular com diâmetro variado, em que se alinhava as bordas e puxa a linha formando uma trouxa de tecido.
} 
Segundo o autor, em Alagoas destacam-se produtos artesanais feitos com palha de coqueiro e taboa, a tecelagem ornamental e as rendas. No Ceará, são produzidas rendas, redes, chapéus, bolsas e cerâmicas. No Maranhão, nas tribos indígenas locais, são criados objetos de palha, penas de pássaros e madeira. Na Paraíba, os principais produtos são a renda renascença, a tapeçaria, o crochê, brinquedos populares, os bordados labirintos e os enxovais em ponto cruz, rococó e richelieu. Em Pernambuco, destacam-se a xilogravura, pintura em tecido, objetos com conchas, redes, cestarias, cangas e panos de prato. No Piauí, as cestarias, objetos feitos com fibras de buriti e carnaúba, além de peças de palha de coco. No Rio Grande do Norte, trançados, vassouras de cipó, esteiras, objetos de palha, cerâmica decorativa, itens de couro e animais de madeira. Em Sergipe, encontra-se a renda irlandesa, a renda de bilro, o bordado richelieu e peças de palha. Na Bahia, o artesanato constitui uma das riquezas culturais do estado, com destaque para artesanato indígena, artesanato mineral6, bordados, trançados, cestaria, rendas, tecelagem, artesanato com madeira e prata, redes de pesca, dentre outros.

Em várias regiões da Bahia, como Maranhão, Piauí, Rio Grande do Norte e Pernambuco, o artesanato com trançados é o sustento de muitas famílias, inclusive de povos indígenas dessas regiões. De acordo com Belarmino (2018), a tribo indígena Kambiwá localizada entre os municípios de Ibimirim, Inajá e Floresta do Sertão pernambucano, sobrevive das técnicas do trançado, expondo suas peças na Feira Nacional de Negócios e Artesanato (FENEART), que acontece todos os anos em Pernambuco. Belarmino (2018) comenta que "a indumentária indígena como saias, bolsas, colares entre outros adereços, possui muitos detalhes trançados, sendo a palha e a fibra uma manufatura acessível para esses povos" (BELARMINO, 2018, p. 14).

Segundo a Artesol (2018) - organização sem fins lucrativos que investe na valorização e promoção do artesanato tradicional brasileiro -, em Costa do Sauípe, no litoral norte baiano, cerca de 300 artesãs reunidas atuam, por meio da cooperativa Copartt, com a produção do chamado Trançado Tupinambá. As peças da Copartt são trançadas com técnicas centenárias dos índios tupinambás. Desses povos nativos, as artesãs herdaram o ritual de colher a palha de piaçava, tratar, tingir a fibra e criar artefatos cotidianos versáteis. Atualmente, a cooperativa fornece peças para grandes redes como a Tok\&Stok e atende a pedidos de grandes marcas.

\footnotetext{
6 Em Morro do Chapéu - BA (conhecida como terra das orquídeas), artesãos esculpem objetos variados em pedras como mármore, calcita, calcário, dolomita, quartzo, entre outras encontradas na região.
} 
As famosas rendas do Nordeste, com destaque para as rendas de bilro no Ceará e Bahia, renda renascença na Paraíba, renda irlandesa em Sergipe, rendas filé e tenerife (ou nhanduti ${ }^{7}$ ) em Alagoas, são exploradas por grandes estilistas em coleções que exaltam a riqueza do Brasil. De acordo com Artesol (2018), em Saubara, na Bahia, a Associação de Artesãos de Saubara divide-se na produção de duas tipologias de artesanato: o trançado de palha e a renda de bilro. O trançado de palha é tradição herdada das índias tupinambás, antigas habitantes da região. A técnica trabalha com a palha seca da palmeira de oricuri ou licuri e é passada de mãe para filha. A técnica de tecer com bilros, presente especialmente em cidades litorâneas e de herança portuguesa, está presente a mais de quatro séculos na região. Em Saubara as rendas se desenvolvem com características próprias, utilizando a técnica herdada e utilizando materiais e instrumentos disponíveis na região.

Em Sergipe, a técnica utilizada pelas rendeiras de Divina Pastora, conhecida como renda irlandesa ${ }^{8}$ ou ponto de Irlanda, foi incluída, em 2009, como Patrimônio Cultural do Brasil. As rendeiras riscam em um papel o desenho que desejam, costuram o lace cordão sedoso e achatado - no papel e elaboram um contorno para a renda. Com a combinação de mais de 20 pontos, elas preenchem os espaços vazios e desenvolvem a renda irlandesa. Os desenhos, formas e aplicações são diversificados e as peças criadas são roupas de cama e mesa, peças de decoração, acessórios e vestuário (ARTESOL, 2018; IPHAN, 2020).

Brahic (1998, p. 7) conceitua a tecelagem manual como "o nome do artesanato que utiliza uma máquina para produzir um tecido a partir de fios. Esta máquina denomina-se tear." No tear, coloca-se uma quantidade de fios mantidos em tensão; esses fios compõem a urdidura, na qual os fios da trama são entrelaçados de forma perpendicular à urdidura. Ainda segundo o autor (Ibidem, p. 8), "o tear artesanal pode produzir desde os tecidos mais grossos até os mais finos, desde os pesados tapetes de lã até aos elegantes damascos de seda".

Para Silveira (2013), a tecelagem, um setor do artesanato, é uma arte que acompanha o desenvolvimento do ser humano desde as civilizações da Antiguidade. Segundo a autora, as primeiras tecelagens podem ter surgido no período Paleolítico ou

\footnotetext{
7 Renda tenerife ou nhanduti é trabalhada em pequenos teares circulares ou quadrados, com desenhos em forma de raios. É originária de Tenerife na Espanha.

8 De acordo com o IPHAN - Instituto do Patrimônio Histórico e Artístico Nacional, a cidade de Divina Pastora destacou-se com a renda irlandesa em razão de condições históricas de produção, que remontam à Europa do século XVII, vinculadas às mudanças econômicas que resultaram na ressignificação de saberes tradicionais e na apropriação popular do ofício de rendeira. Assim, a renda irlandesa de Divina Pastora é trabalhada com matéria-prima com características próprias, recriando uma renda original e sofisticada. Disponível em: <http://portal.iphan.gov.br/pagina/detalhes/68>. Acesso em: 27 set. 2020.
} 
Mesolítico - sendo difícil precisar as datas devido à fragilidade das fibras que são suscetíveis à ação do tempo. Mas, apesar das grandes transformações ocorridas até então, a tecelagem manual ainda continua viva através de artesãos e designers que dialogam em favor da criação de inúmeros produtos, inclusive na área da moda. Hoje, esses profissionais unem técnicas tradicionais a materiais industrializados e esse entrelaçamento resulta em diversas possibilidades de desenvolvimento de tecidos manuais criativos.

A arte do tecer artesanal está muito presente na região nordeste. De acordo com Artesol (2018), no Piauí, as tecelãs manipulam diversas técnicas, como a tapueirana9 ${ }^{9}$ o ponto catado, olho de pombo, entre outros, para construção de redes, tapetes, bolsas e colchas. São peças coloridas e estampadas feitas com fibras naturais, produzidas em tecelagem de grade e de parede, tecidas manualmente. Em Barrocas, na Bahia, a tecelagem possui uma forte marca da influência indígena, que se torna evidente no uso do tear vertical - tipo de grade de madeira em que a tecelã executa seu trabalho sentada no chão e bate os fios da trama com um pente. O resultado é um tecido encorpado e colorido e os desenhos são os responsáveis pela textura.

Em Alagoas, no município de Delmiro Golveia, por um tempo acreditou-se que a vocação da tecelagem manual estivesse extinta, porém um grupo de mulheres retomou a tradição artesanal da tecelagem manual que tinham aprendido com suas mães e avós e participam da Tecelagem Descanso do Rei onde trocam e compartilham seus saberes, potencialidades e possibilidades. Elas dominam as técnicas de redes, mantas, passadeiras, jogos americanos, entre outros produtos. Já em Pedro II, município de Piauí, a tecelagem artesanal ganha destaque com colchas de cama, redes, jogos americanos, mochilas, sacolas de viagem e estojos de viagem feitos em tecidos criados em teares de grade e de parede. A técnica é passada de geração a geração (ARTESOL, 2018).

\section{Cores de Chita: inspiração e técnicas}

A pesquisa teve suas inspirações norteadas por vivências pessoais da pesquisadora, por disciplinas trabalhadas no Curso de Design de Moda, pelo envolvimento de seus antepassados com o fazer artesanal e saberes tradicionais, assim como, pelas pesquisas bibliográficas e imagéticas.

9 Técnica para fazer um tipo de rede de dormir, caracterizada pela mescla de diversas cores. 
O processo de produção têxtil, seja com a utilização de fibras naturais ou não, principalmente na etapa de beneficiamento, implica em algum desperdício, descarte inapropriado, poluição das águas, dentre outros. Introduzir os princípios da sustentabilidade no segmento de moda é um grande desafio, pois incide em todas as etapas do processo produtivo, demandando habilidades para se manter no mercado atendendo os desejos dos consumidores cada vez mais exigentes quanto à qualidade e bom preço.

Um novo conceito que vem ganhando espaço na moda é o upcycling (reutilização têxtil), que segundo Lucietti et al. (2018) é uma técnica que consiste no reaproveitamento de retalhos, sobras e peças que seriam descartadas para a construção de novas peças originais, sem gastar mais energia na reutilização do mesmo, diferente da reciclagem, visando a redução do desperdício de matérias primas. O upcycling "é um processo de recuperação que transforma os resíduos desperdiçados em novos produtos ou materiais com superior qualidade e valor ambiental" (ANICET; BESSA; BROEGA, 2011, p. 3).

Contudo, para Lucietti et al. (2018), a técnica de upcycling pode ser desafiadora, já que o designer deverá fazer uma seleção cuidadosa dos resíduos e deverá escolher um acabamento final que atrele qualidade ao novo produto para despertar o interesse dos consumidores. A reutilização têxtil torna a moda mais consciente e criativa e já está presente em vários projetos de marcas.

Pensando em todo esse contexto de sustentabilidade, a pesquisa para desenvolvimento de têxteis artesanais, utilizados em uma coleção de bolsas, envolveu o trabalho com a reutilização têxtil com vistas a diminuir o desperdício, de forma possível, na construção de suas peças, unindo características do fazer artesanal, técnicas de sustentabilidade e características específicas dos tecidos de algodão, como os detalhes desfiados, criando peças com um toque rústico, porém delicado.

Aos estudos e interesses - sobre artesanato, cultura têxtil nordestina e reutilização têxtil - somaram-se a trama em tear de pregos utilizando barbante, a renda manual feita com agulha e o uso da chita em vestidos infantis trabalhados por Alzira, avó da pesquisadora. Os saberes da dona Alzira tornaram-se uma das fontes de inspiração para o desenvolvimento da pesquisa para o Trabalho de Conclusão de Curso, pois engloba saberes tradicionais, o fazer artesanal de têxteis e a identidade cultural de um povo - saberes que remetem a um passado familiar não vivenciado, mas trabalhado aos poucos. 
Juntamente às inspirações vindas da dona Alzira e dos seus saberes, surgem outras inspirações que nortearam o desenvolvimento de todo o projeto, quais sejam: trabalhos com técnicas tradicionais, materiais sustentáveis e objetos com formas, cores e texturas variadas. São trabalhos artesanais em trançados, tear e rendas, objetos, ambientes e muitas cores (Figura 1).

Para o desenvolvimento dos têxteis desta pesquisa utilizou-se retalhos de tecido em algodão. São tecidos com ligamentos em tafetá ou sarja como, o algodão cru, o denim (jeans) e a chita. O uso do algodão deve-se ao fato dessa fibra vegetal ser mais resistente e não elástica, o que facilita o processo de tecelagem manual, porque mantem a tensão necessária e garante maior durabilidade ao produto final. Por ser uma fibra que suporta grande tensão, o algodão é usado principalmente na urdidura dos tecidos.

A fibra do algodão dá origem ao tecido de chita, tecido de algodão estampado originário do Oriente, Índia medieval, que chegou ao Brasil em 1498 e hoje faz parte da cultura brasileira. O tecido popular e barato que vestia a classe trabalhadora (camponeses e escravos), aos poucos ganhou destaque (PEZZOLO, 2009).

A chita, composta por tramas simples, é um tecido de algodão chamado morim, caracterizado por suas estampas coloridas. Atualmente, dividida em chitão e chitinha, (conforme a dimensão de suas estampas), a chita ganha espaço e está presente em grandes criações de designers.

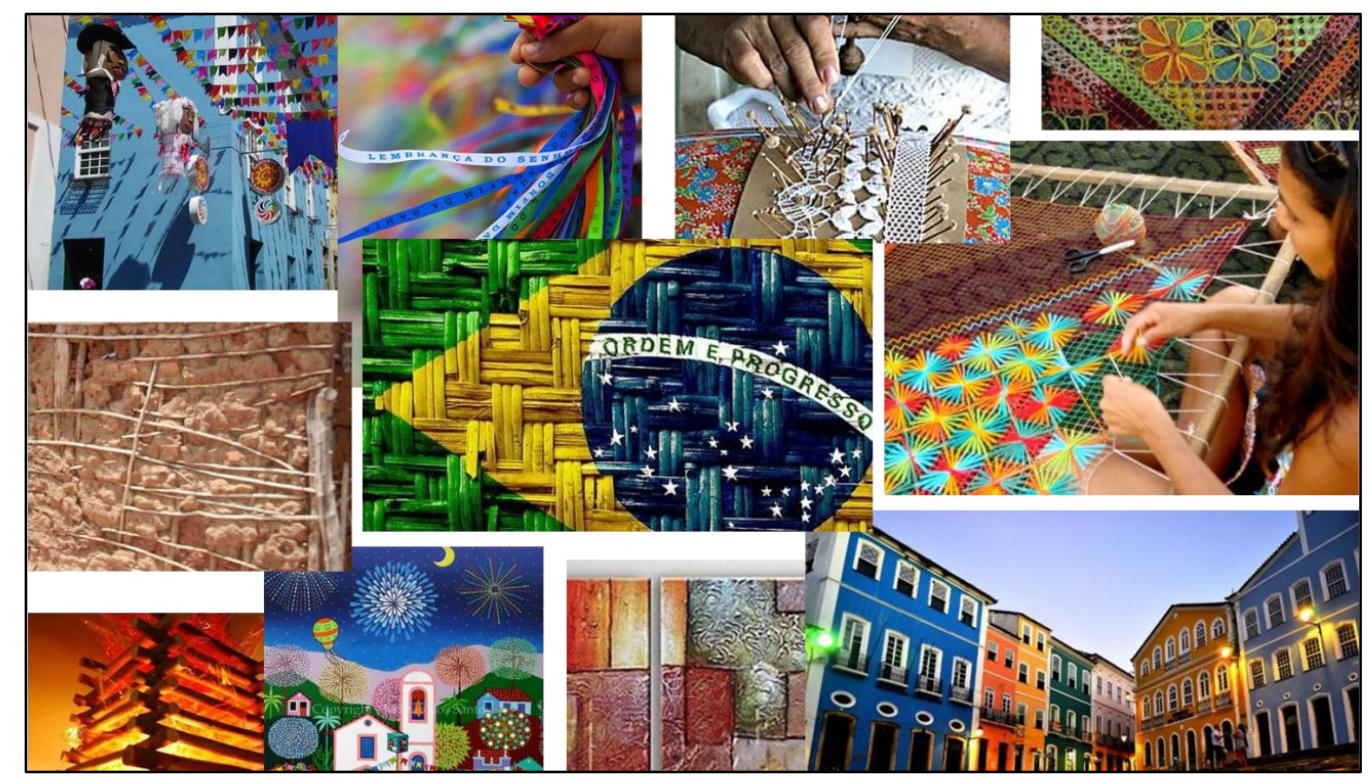

Figura 1: Painel de inspiração Fonte: Compilação da autora ${ }^{10}$

10 Montagem a partir de imagens coletadas do site pinterest.com, em pastas sobre artesanato e cultura. 
A pesquisa tem por objeto a chita em sua expressão mais marcante de cores com vistas a valorizar o tecido e sua história. As cores tropicais, representativas do Brasil e de sua vasta riqueza nativa e cultural, foram inseridas nos têxteis, não apenas através do uso da chita, mas também dos bordados coloridos que complementaram todo o desenvolvimento têxtil do projeto. A valorização do tecido chita reflete diretamente na cultura do país:

A abrangência atual da chita no que diz respeito tanto às suas mais diversificadas utilizações, bem como geográfica e economicamente falando, é exemplo de superação e sucesso e nos faz perceber a imensa riqueza das possibilidades que a natureza nos proporciona. Este tecido faz-nos compreender o quanto é importante a valorização da representação da nossa cultura, do nosso povo, do nosso país nos projetos de design. Apesar de ter vindo de outros mares, trazida pelos colonizadores, foi aqui que ela se encontrou, se transformou e hoje é considerada uma manifestação popular e um tecido totalmente brasileiro (ROCHA; QUEIROZ, 2010, p. 10).

As inspirações movidas pela identidade cultural de um povo, especificamente a baiana, englobam a cultura e o artesanato ligado aos têxteis que vão desde o uso do tecido chita nas manifestações culturais do estado (festa junina e carnaval), na decoração de casas de fazenda e de resorts de luxo e do vestuário (que atualmente está sendo mais explorado por estilistas), até a trabalhos de artesãs, tecelãs e rendeiras que constroem histórias por meio de trabalhos manuais. O conjunto dessas inspirações lançam aspirações para um patamar autoral e único com valor cultural.

Com a utilização de conceitos e técnicas de tecelagem, artesanato, identidade cultural do Nordeste e reutilização têxtil, o produto final desta pesquisa consistiu no desenvolvimento artesanal e de forma sustentável de tecidos, criados para a coleção de bolsas intitulada Cores de Chita. A coleção é composta por doze bolsas, das quais seis bolsas foram selecionadas para serem confeccionadas com os tecidos artesanais.

\section{Cores de Chita: desenvolvimento}

A paleta de cores, composta por dez cores, foi retirada do conjunto das inspirações, em especial das cores dos tecidos de chita. Os tons, com base na Pantone, foram nomeados de acordo com o tema da coleção: Areia rendá, Amarelo solar, Laranja Bahia, Vermelho índia, Rosa Gabriela, Azul verão, Azul recicle, Verde mar, Verde palma e Negro Pelô. 
A escolha de materiais pautou-se em pesquisas imagéticas, inspirações, cartela de cores e no conceito de upcycling. Para os tecidos artesanais, foram utilizados materiais têxteis com composição de $100 \%$ algodão sem elasticidade, facilitando a tecelagem em tear de pregos: retalhos, sobras e peças (já sem utilização) de chita, algodão cru e jeans. O forro das bolsas foi trabalhado com algodão cru com apliques de chita.

Para a urdidura dos têxteis artesanais, foram escolhidos barbantes n. 4 e n. 6 de cores variadas, baseadas na paleta de cores da coleção. Outros tipos de fios e barbantes foram escolhidos para acabamentos, alças e complementos, como: barbante com brilho dourado, barbante felpudo, fios para crochê em algodão, fio sintético para alguns detalhes e fio metalizado dourado.

As ferragens e detalhes metalizados foram escolhidos na cor dourada remetendo à predominância do sol no Nordeste. As ferragens compreendem argolas e meia argolas, pés bailarina, cursor de zíper, corrente, mosquetão, botão magnético e terminal para tassel para os complementos das bolsas. Nas pedrarias, foram escolhidas miçangas, vidrilhos e paetês.

Para estruturar os tecidos e bolsas, foram utilizados entretela termocolante, entretela de malha, entretela para bordado e E.V.A. de $1 \mathrm{~mm}$ e $2 \mathrm{~mm}$. A estrutura de algumas alças foram trabalhadas com mangueira de $8 \mathrm{~mm}$. Para as costuras, utilizaramse linhas de algodão, poliéster e nylon. Optou-se por empregar o zíper em nylon grosso em cores variadas. Para o acabamento interno de algumas bolsas foi utilizado viés de algodão.

A criação de todas as bolsas seguiu inspirada nas cores do tecido chita - cores primárias e secundárias, puras e saturadas que dialogam com cores quentes e frias -, com o trabalho de formas básicas geométricas, como quadrado, retângulo, trapézio e triângulo. Essas formas foram retiradas do painel imagético de formas, tendo por inspiração elementos arquitetônicos do Pelourinho e Quadrado de Trancoso na Bahia, elementos culturais, como decoração em bandeirolas juninas e colchas de retalhos formadas por junção de tecidos feitos em tear, além da própria forma do tear artesanal quadrado e retângulo. No design de superfície, as texturas dos tecidos artesanais, bordados e aplicações de cordões artesanais ganham destaque. Assim, as bolsas remetem a uma cultura rica e exuberante, integrando design, sustentabilidade e valor simbólico.

A coleção está dividida em quatro famílias que foram pensadas a partir de todo o conjunto de inspirações juntamente às obras de dois escritores nordestinos, um 
compositor e um poeta. As obras exaltam a cultura nordestina e remetem a pontos específicos da pesquisa como os trançados, rendas, flores da chita e tear. Assim, para cada família foi desenvolvido um design têxtil específico.

A família Tranças de Iracema foi inspirada no romance Iracema (1865) do consagrado escritor cearense José de Alencar, e a principal característica são os trançados. A família Olê, mulher rendeira baseou-se na letra da música Mulher Rendeira, versão do paraibano Zé do Norte e foi trabalhada com a técnica de renda tenerife e rede com nós de macramê. A terceira família Flores de Gabriela foi inspirada na obra do baiano Jorge Amado, Gabriela, Cravo e Canela, de 1958, e sua principal característica são as flores e cores. A última família Tece Tecelã criou vida através do poema $A$ tecelã do poeta pernambucano Mauro Mota e tem como ponto forte a tecelagem artesanal e manual.

Após alguns experimentos de tecelagem no tear de pregos foram criadas pequenas amostras de tecidos artesanais. Para o desenvolvimento têxtil, um tear de pregos artesanal e multiformas com capacidade de construção de têxteis de aproximadamente $60 \times 60$ centímetros foi montado. O tear foi manejado na forma de pente liço criando tecidos com padrões mais básicos em tela. Na urdidura, utilizaram-se barbantes e a trama foi trabalhada com os retalhos de tecidos em algodão e barbantes. Assim, iniciou-se a produção artesanal dos têxteis, com base nas famílias da coleção, utilizados para desenvolvimento das bolsas (Figura 2).

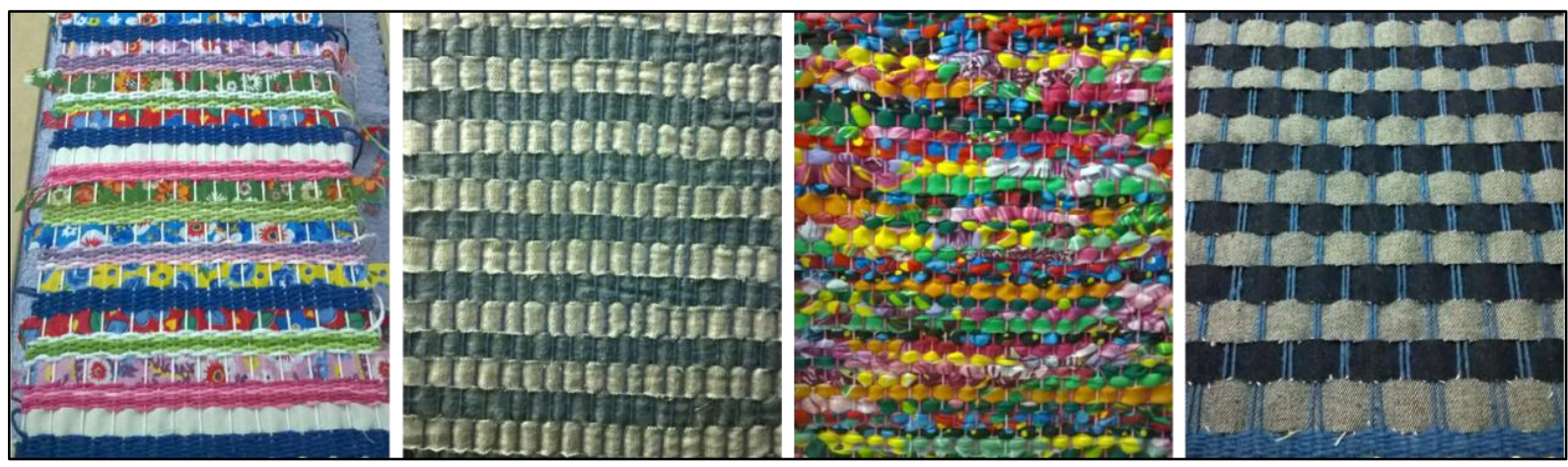

Figura 2: Exemplos de tecidos artesanais finalizados Fonte: Arquivo pessoal

Por se tratarem de retalhos de têxteis em algodão, que se desfiam com facilidade, os tecidos ganharam um toque único, apresentando-se como rústicos, porém delicados. Os detalhes de desfiado associam não apenas ao fazer artesanal, mas a toda questão da sustentabilidade, por trabalhar com resíduos têxteis. 
Algumas etapas foram fundamentais para o desenvolvimento da coleção, a saber: a) os croquis (Figura 3) e desenhos técnicos, b) a elaboração das fichas técnicas, c) a modelagem, d) a construção dos protótipos das peças, e) passamanarias artesanais, f) o desenvolvimento do tecido para os forros das bolsas, g) tecido construído a partir dos resíduos de têxteis e aviamentos coletados durante todo o processo, h) caderno de processos, i) book da coleção e j) editorial.

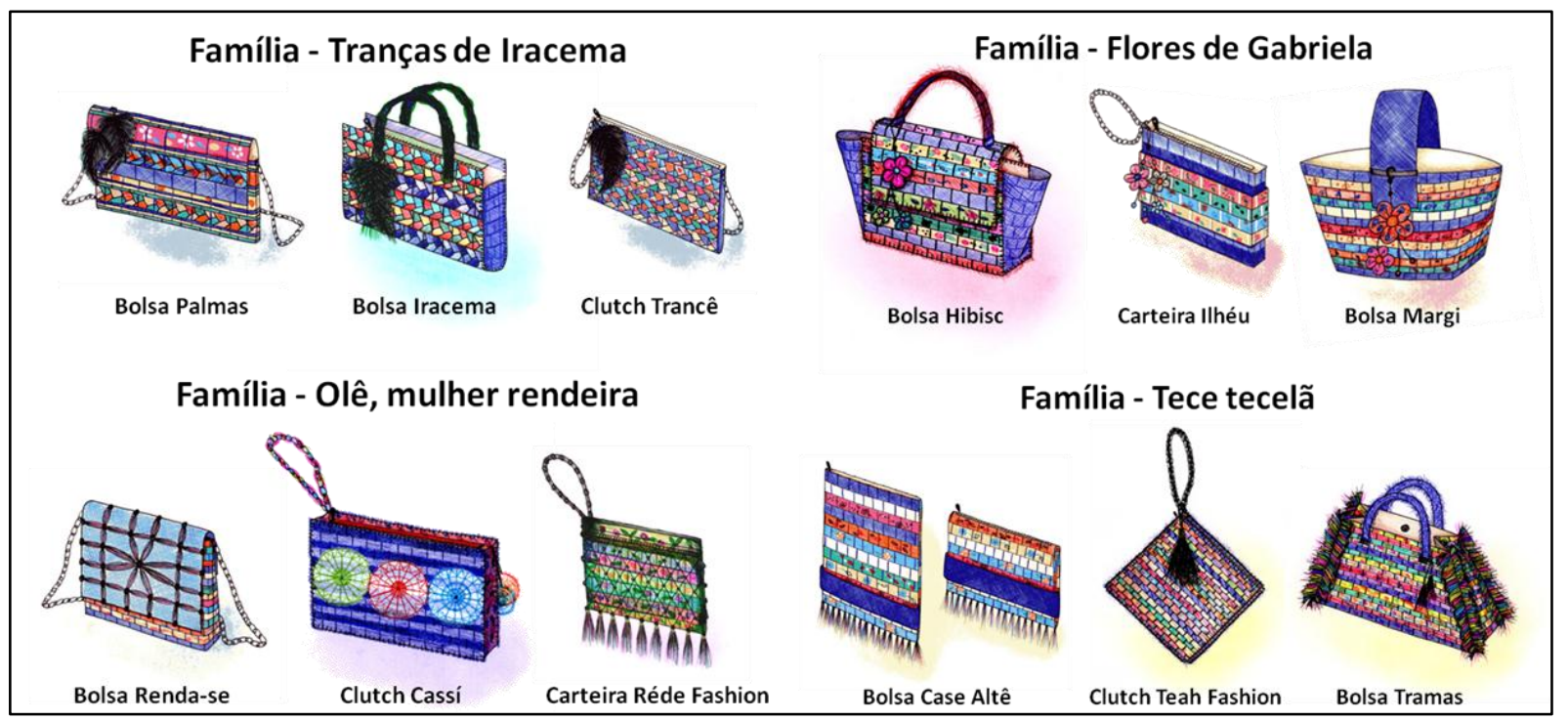

Figura 3: Croquis da coleção por famílias

Fonte: Ilustrações da autora

Com a construção dos protótipos, foi possível analisar algumas questões relacionadas ao design como a funcionalidade, como o tamanho dos bolsos internos (de forma a caber um smartphone de porte médio ou documentos), e o conforto das peças, como o tipo de fecho e zíper utilizado em peças pequenas e mais delicadas.

Com inspiração nos vestidos infantis de chita enfeitados com passamanarias, produzidos pela avó Alzira, alguns detalhes de barbantes trançados a fios metalizados foram acrescentados ao tecido mais delicado elaborado com as tiras de retalhos abertas e sem dobras. Além de dar um detalhe especial, as passamanarias artesanais contribuem para dar maior resistência ao tecido.

Para o forro das peças, foram escolhidos os tecidos de algodão cru e chita. Ambos os tecidos foram trabalhados de forma a se constituírem em um novo tecido, mais elaborado com a técnica de apliques e bordados feitos na máquina doméstica. Do tecido de chita com estampas grandes (chitão) foram recortadas flores e folhas. Esses recortes 
receberam uma entretela termocolante utilizada para patchwork ${ }^{11}$, e foram aplicadas no tecido de algodão cru e bordados à máquina (Figura 4).

Todos os resíduos têxteis e de aviamentos, como barbantes, fios, linhas e cordões foram coletados durante todo o processo da pesquisa e, a partir deles, foi construído um novo tecido que foi utilizado para a construção da capa do book de coleção, além da construção de portas-moeda, confeccionados para cada uma das bolsas. A técnica consistiu em um 'sanduíche' de resíduos entre o tecido de morim e uma tela de filó. Após a sobreposição desses materiais, foi feito um trabalho de quilting ${ }^{12}$ (à mão livre na máquina doméstica) no novo tecido para que os resíduos não ficassem soltos dentro do 'sanduíche' (Figura 5).

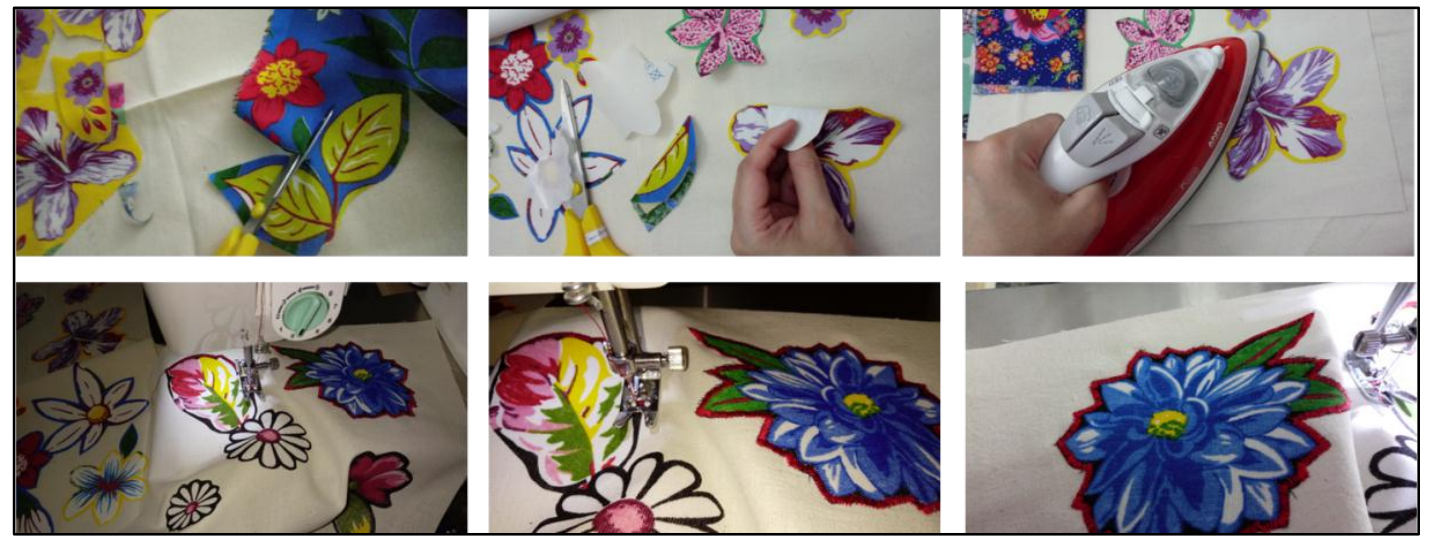

Figura 4: Tecido interno em algodão cru bordado com retalhos de chita Fonte: Arquivo pessoal

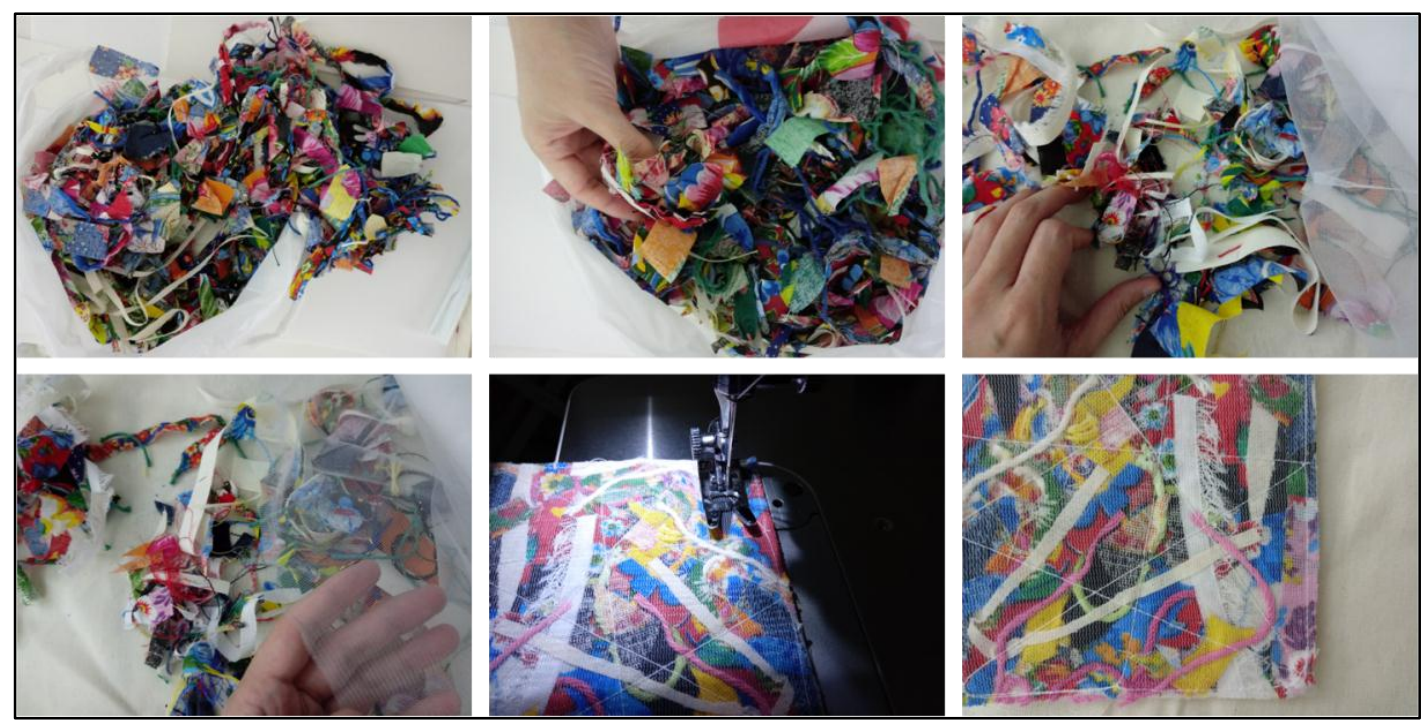

Figura 5: Resíduos coletados e criação de novo têxtil Fonte: Arquivo pessoal

\footnotetext{
${ }^{11}$ Patchwork é o trabalho artesanal com retalhos de têxteis com cores, formas e texturas variadas. ${ }^{12}$ Quilting é uma técnica utilizada no artesanato e significa acolchoamento.
} 


\section{O produto final: bolsas}

Dentre as doze bolsas da coleção, foram analisadas características mais específicas de acordo com cada família, a saber: design, tamanho, forma e usabilidade, para escolher quais as bolsas seriam confeccionadas. Dessa forma, foram escolhidas seis peças: a) da família Tranças de Iracema optou-se pela bolsa de mão Iracema; b) da família Olê, mulher rendeira foram escolhidas a clutch Cassí e a carteira de mão Réde Fashion; c) da família Flores de Gabriela foi escolhida a bolsa de mão Hibisc; e, d) da família Tece tecelã foram escolhidas as bolsas clutch Teah Fashion e a bolsa de mão Tramas.

Os formatos das bolsas seguiram uma linha mais simples, revezada entre quadrados e retângulos de tamanhos variados, inspirados no design mais básico e reto, aproximando-se do design conceitual no que tange à funcionalidade e usabilidade projetual do produto. Dessa forma, o que se sobressai nas bolsas são seus valores culturais, sua funcionalidade e seu aspecto sustentável, representados no uso de retalhos, cores, detalhes mais rústicos com os desfiados e texturas.

Por ser confeccionada com tecidos artesanais mais estruturados e possuírem estrutura em E.V.A., as bolsas foram costuradas de forma a deixar o acabamento mais rústico, com desfiados aparentes. Assim, as costuras são visíveis e o desfiado natural dos retalhos têxteis que compõem o tecido artesanal concorda com os desfiados do acabamento mais cru. As costuras bases foram feitas na máquina doméstica e o caseado mais discreto nas bordas das bolsas, feitos à mão, reforçam a estrutura sem interferir na textura dos têxteis.

Outras técnicas tradicionais foram trabalhadas para proporcionar melhor acabamento e complementar as peças. Além da tecelagem artesanal, utilizou-se a técnica de trançado, macramê, rendas rede com nós de macramê e renda Tenerife ou nhanduti, tricô em tear, a técnica de fuxico, bordados com apliques e bordado de pedrarias e caseado (Figura 6).

As aplicações de pingentes, flores e/ou bordados também seguiram as características de cada família da coleção, que ganharam detalhes como pingentes em formato de folhas, flores e franjas. Esses detalhes, além de relacionarem-se a cada família, também se baseiam na flora brasileira retratada nas estampas da chita: folhas de coqueiro, folhas de palmeiras como licuri, carnaúba e buriti, flores e frutos. 
Para um bom equilíbrio e composição das bolsas, foram observados alguns princípios do design, assim como a harmonia das cores tanto na criação dos tecidos artesanais, forro, pingentes, rendas e na peça como um todo. As cores e estampas foram intercaladas com outras ou mesmo com jeans e o cru do algodão, observando repetição, ritmo, gradação, contraste e harmonia (Figura 7).

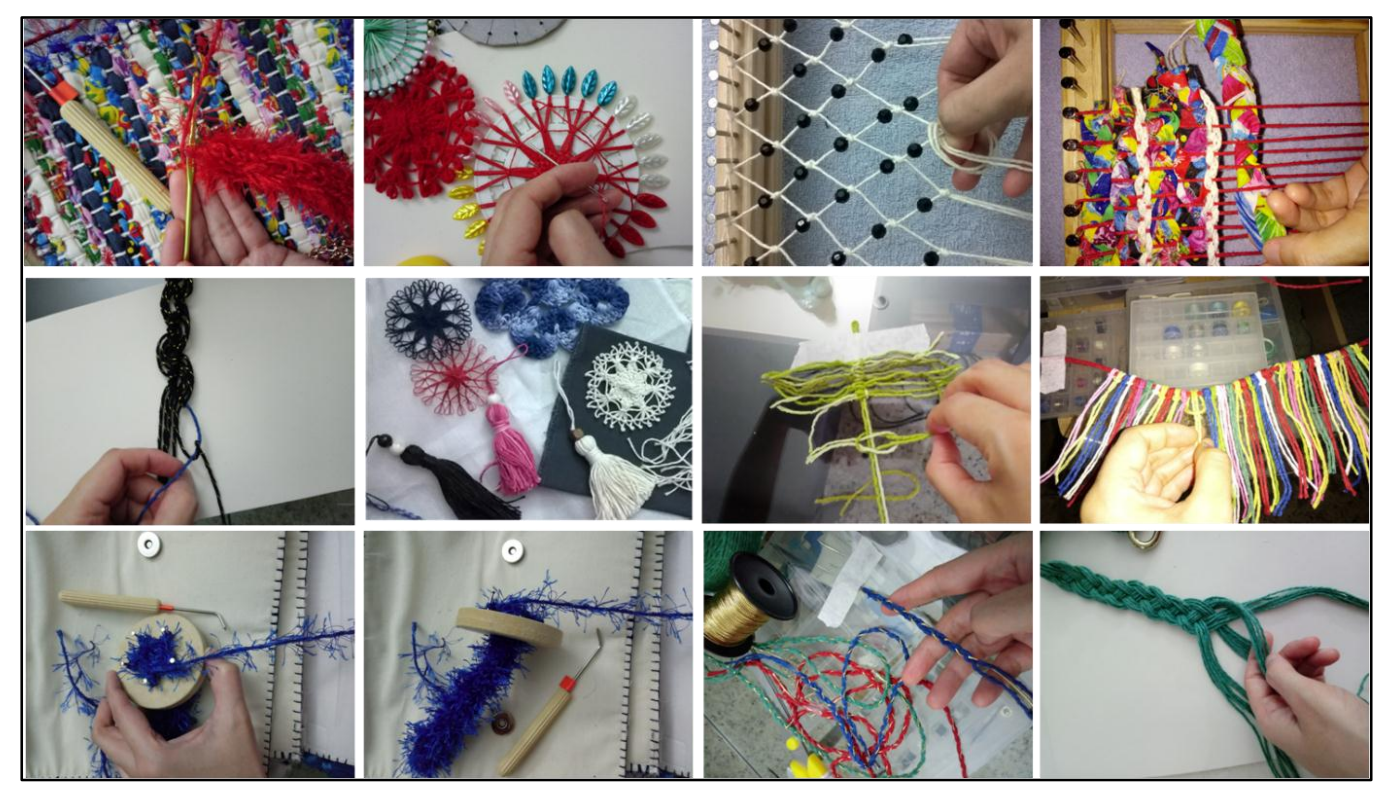

Figura 6: Técnicas tradicionais e artesanais Fonte: Arquivo pessoal

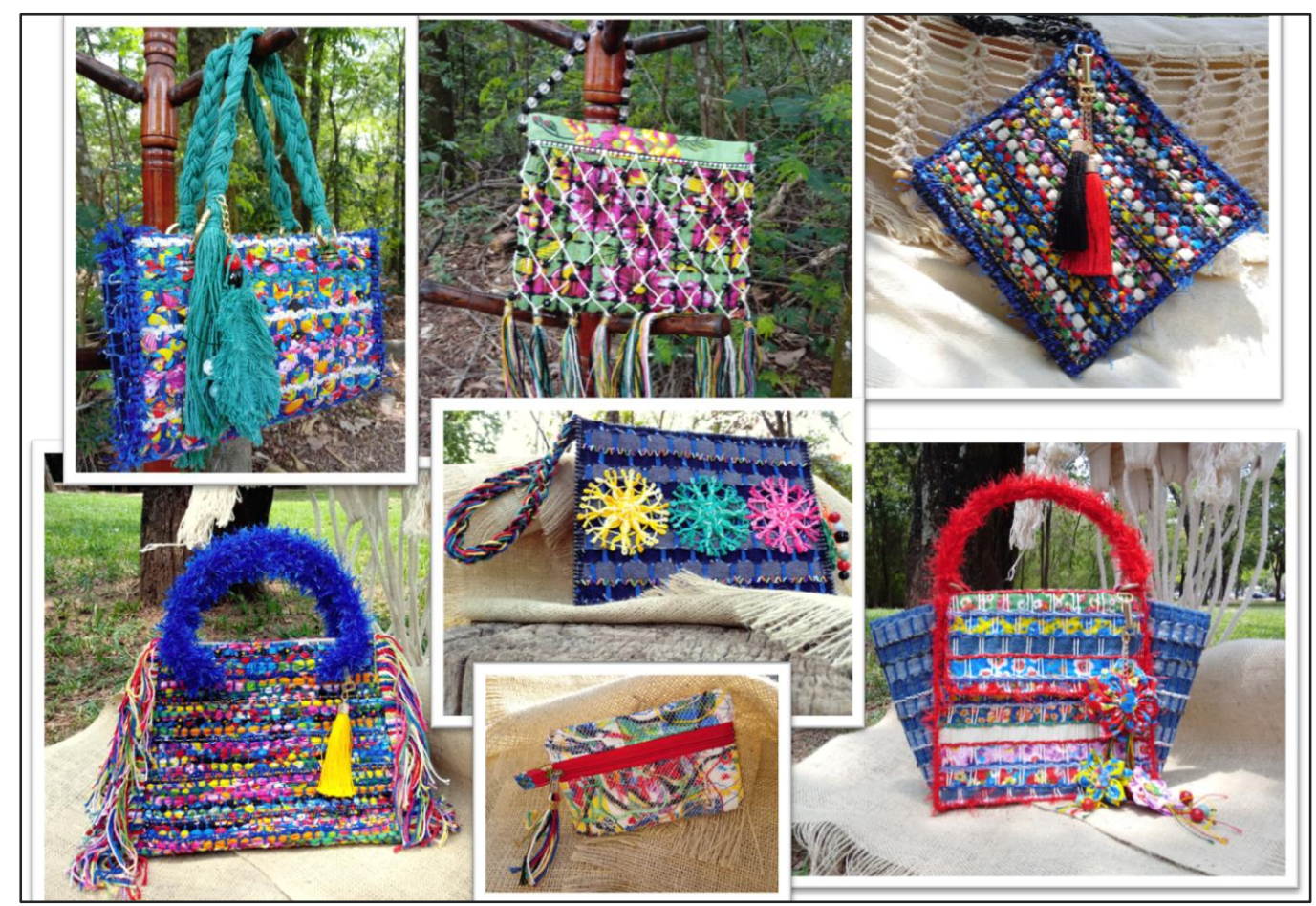

Figura 7: Produto final. Bolsas artesanais e porta-moeda Fonte: Arquivo pessoal 


\section{Considerações finais}

A proposta inicial do projeto foi mantida, tendo em vista que a coleção Cores de Chita satisfez o objetivo da pesquisa com a criação de tecidos em tear manual de pregos, com a técnica de reutilização têxtil, para o desenvolvimento de uma coleção de bolsas inspiradas em aspectos culturais do Nordeste do Brasil. Por meio das técnicas de tecelagem e reutilização de têxteis, foram aproveitados retalhos de tecidos e aviamentos sem uso. Técnicas, a exemplo do tricô e da renda em tear remeteram às rendas e aos trançados do Nordeste. A paleta de cores, por sua vez, ressaltou as cores do tecido chita e a coleção ganhou expressividade ao representar o fazer artesanal e a identidade cultural do Nordeste.

O processo de desenvolvimento dos têxteis nos teares de pregos criou texturas ricas e diversas. O uso de retalhos, sobras de tecidos e barbantes, com textura, espessura e cores diferentes resultou em tecidos com características únicas e personalizadas para cada bolsa. A mistura de tecidos e o detalhamento das tramas acompanharam a riqueza das rendas, trançados e cores do artesanato do Nordeste.

Em algumas peças de tecidos a paleta de cores, inspiradas na chita, aparece com mais força nas tramas dos tecidos com a combinação de retalhos e barbantes coloridos, enquanto que em outras, com tramas mais neutras, as cores se destacam nos bordados com pedrarias e passamanarias ou nas rendas e pingentes das peças. Dessa forma, alcançou-se uma variedade de tramas e modelos, tornando a coleção mais rica e diversificada.

Com modelagem em linhas retas, explorando formas quadradas, retangulares e de trapézio, as bolsas apresentam texturas variadas que dependem do tamanho, espessura e comportamento do retalho, do tipo de trama, de técnicas de tecelagem e do design de superfície aplicado em cada peça. As estruturas dos têxteis se adequaram aos modelos e formas escolhidas das bolsas, gerando equilíbrio e conexão entre tecidos, texturas, formatos, aviamentos e bordados das peças, contribuindo para uma estética alegre e convidativa ao público consumidor.

A partir da elaboração dos protótipos, mesmo sendo construídos em material de espessura distinta do tecido elaborado no tear de pregos, foi possível analisar as proporções desejadas das bolsas, sua funcionalidade e conforto adequados ao uso proposto. Dessa forma, a construção dos produtos finais manteve seu design e modelagem de forma a contribuir para a valorização das técnicas utilizadas nos têxteis. Assim, os tecidos artesanais destacam-se nas peças finais. 
A utilização da técnica sustentável de reutilização (upcycling) com o uso de retalhos se mostrou eficaz quanto ao reaproveitamento de têxteis. Além de valorizar as peças com retalhos de tecidos com textura e cores diferentes entre si, criando tecidos únicos, gerou o mínimo de resíduo possível. No entanto, o resíduo gerado durante o processo ainda foi significativo. Assim, visando um total aproveitamento dos restolhos, estudou-se algumas opções para aplicação completa dos restos e se chegou no desenvolvimento de um novo tecido utilizado para a capa do book da coleção e para produção de porta-moedas, contribuindo para a sustentabilidade dentro dos meios de produção de moda com descarte zero.

As bolsas associam valores que remetem tanto a questões de sustentabilidade quanto a diversificação e riqueza da identidade nordestina. Dessa forma, trabalham design e artesanato, valorizando o trabalho artesanal, a tecelagem em tear manual e o designer de moda. As peças possuem detalhes característicos que refletem produtos sustentáveis, que valorizam regiões, tradições e culturas, aliados à qualidade.

As peças da coleção transparecem os conceitos de design, na busca por soluções para questão ambiental, usabilidade, qualidade e aspectos visuais, e artesanato resgatando saberes tradicionais do passado com técnicas manuais e traduzindo-os para o presente. Além disso, as bolsas representam o conceito de upcycling. As peças finais ressaltam a valorização do mercado cultural brasileiro, contribuindo para uma visão mais consciente do momento atual, não somente dentro da moda, mas dentro do contexto social, econômico e cultural. Em suma, este projeto alcançou soluções positivas para a sociedade, que convive com o problema da poluição causada pela indústria têxtil.

\section{Referências}

ABIT - Associação Brasileira da Indústria Têxtil e de Confecção. Perfil do setor. 2019. Disponível em: <http://www.abit.org.br/cont/perfil-do-setor>. Acesso em: 27 set. 2020.

ALENCAR, J. de. O guarani; Iracema; Ubirajara: romance brasileiro. [S.I.]: [s. n.], [19-?]. 326 p.

AMADO, J. Gabriela, cravo e canela: crônica de uma cidade do interior. 6. ed. São Paulo: Martins, 1959. 453p. (Obras de Jorge Amado;14)

ANICET, A.; BESSA, P.; BROEGA, A. C. Ações na área da moda em busca de um design sustentável. In: COLÓQUIO DE MODA, 7., 2011, Maringá, PR. Anais eletrônicos... Maringá: [s.n.], 2011. Disponível em: <http://www.coloquiomoda.com.br/anais/ Coloquio\%20de\%20Moda\%20-\%202011/GT11/GT/GT89897_Acoes_na_area_da_moda_ em_busca_de_um_design_sustentavel.pdf>. Acesso em: 20 ago. 2018. 
ARTESOL. Organização sem fins lucrativos, 2018. Página Inicial. Disponível em: <http://www.artesol.org.br/novo/>. Acesso em: 24 set. 2018.

AZEVEDO JUNIOR, J. G. de. Apostila de Arte - Artes Visuais. São Luís: Imagética Comunicação e Design, 2007. 59 p.: il.

BELARMINO, C. M. Tramas indígenas: a técnica do trançado da etnia Kambiwá. 2018. 167 f. Dissertação (Mestrado em Artes Visuais) - Programa Associado da Pós Graduação em Artes Visuais das Universidades Federais de Pernambuco e da Paraíba. Recife, 2018. Disponível em: <https://repositorio.ufpe.br/bitstream/123456789/30876/1/DISSERTA\% C3\%87\%C3\%830\%20Clarissa\%20Machado\%20Belarmino.pdf >. Acesso em: 10 jun. 2019.

BENZ, I. E.; LESSA, W. Reflexões sobre uma relação assimétrica entre designers e artesãos. Estudos em design, Rio de Janeiro, v. 24, n. 1, p. 1, 2016. Disponível em: <https://estudosemdesign.emnuvens.com.br/design/article/view/294>. Acesso em: 24 ago. 2018.

BOTELHO, C. Moda: criações artesanais e autossustentáveis. Revista Continente, Companhia Editora de Pernambuco - CEPE, Santo Amaro - Recife. 1 mar. 2016. Disponível em: <https://www.revistacontinente.com.br/edicoes/183/moda--criacoesartesanais-e-autossustentaveis>. Acesso em: 27 set. 2019.

BRAHIC, M. A tecelagem. Lisboa: Estampa, 1998. 192 p.

BRASIL. Ministério do Desenvolvimento, Indústria e Comércio Exterior. Base conceitual do artesanato brasileiro. Brasília: Programa do Artesanato Brasileiro (PAB), 2012. 66 p. Disponível em: <http://docplayer.com.br/7335-Base-conceitual-do-artesanatobrasileiro.html>. Acesso em: 26 ago. 2018.

FIGUEIREDO, M. D. de; MARQUESAN, F. F. S. Artesanato, Arte, Design... Por que Isso Importa aos Estudos Organizacionais? RIGS - Revista Interdisciplinar de Gestão Social. UFBA, Salvador - BA, set./dez. 2014, v. 3, n. 3, p. 127-143. Disponível em: <https://portalseer.ufba.br/index.php/rigs/article/view/8508/11629>. Acesso em: 20 out. 2019.

FRANÇA, R. A. Design e artesanato: uma proposta social. Revista Design em Foco, Salvador, v. 2, n. 2, pp. 9-15, jul./dez. 2005. Disponível em: <https://www.redalyc.org/pdf/661/66120202.pdf>. Acesso em: 21 ago. 2018.

GROPIUS, W. O manifesto da Bauhaus de 1919. Goethe - Instituto Cultural de âmbito internacional da República Federal da Alemanha, 2018. Disponível em: <https://www.goethe.de/ins/br/pt/kul/fok/bau/21394277.html>. Acesso em: 19 out. 2019

HALL, S. A identidade cultural na pós-modernidade. Tradução de Tomaz Tadeu da Silva e Guaracira Lopes Louro. 11. ed. Rio de Janeiro: DP\&A, 2006. 104p.

HATTA, K. S.; SANTOS, V. S. dos; COSTA, M. Como a moda se inspira na arte a fim de agregar valor aos seus produtos. In: COLÓQUIO DE MODA, 9, 2013, Fortaleza. Anais eletrônicos... Fortaleza: [s.n.], 2013. Disponível em: <http://www.coloquiomoda.com.br/anais/Coloquio\%20de\%20Moda\%20-\%202013/ POSTER/EIXO-3-CULTURA\%20_POSTER/Como-a-moda-se-inspira-na-arte-a-fim-deagregar-valor-aos-seus-produtos.pdf>. Acesso em: 24 ago. 2018. 
IPHAN - Instituto do Patrimônio Histórico e Artístico Nacional. Modo de Fazer Renda Irlandesa. Brasília - 2020.2 DF, Disponível em: <http://portal.iphan.gov.br/pagina/detalhes/68>. Acesso em: 27 set. 2020.

KASHIMOTO, E. M.; MARINHO, M.; RUSSEFF, I. Cultura, Identidade e Desenvolvimento Local: conceitos e perspectivas para regiões em desenvolvimento. Interações - Revista Internacional de Desenvolvimento Local, v. 3, n. 4, mar. 2002, p. 35-42. Campo Grande - MS. Disponível em: <http://www.interacoes.ucdb.br/article/view/575/613>. Acesso em: 15 out. 2019.

LIMA, C. V. de S. et al. Desenvolvimento de artefato de moda em tear artesanal com referências culturais. In: COLÓQUIO DE MODA, 9, 2013, Fortaleza. Anais eletrônicos... Fortaleza: [s.n.], 2013. Disponível em: <http://www.coloquiomoda.com.br /anais/Coloquio\%20de\%20Moda\%20-\%202013/COMUNICACAO-ORAL/EIXO-1-DESIGN_ COMUNICACAO-ORAL/Desenvolvimento-de-Artefato-de-Moda-em-tear-artesanal-com-Ref erencias-Culturais.pdf>. Acesso em: 24 ago. 2018.

LUCIETTI, T. J. et al. O upcycling como alternativa para uma moda sustentável. In: INTERNATIONAL WORKSHOP - ADVANCES IN CLEANER PRODUCTION NETWORKACADEMIC WORK, 7., 2018, Barranquilla, CO. Anais eletrônicos... Barranquilla: [s.n.], 2018. Disponível em: <http://www.advancesincleanerproduction.net/7th/files/sessoes /6A/3/lucietti_tj_et_al_academic.pdf>. Acesso em: 21 ago. 2018.

MONTEMEZZO, M. C. de F. S. Diretrizes metodológicas para o projeto de produtos de moda no âmbito acadêmico. 2003. 97 f. Dissertação (Mestrado) - Faculdade de Arquitetura, Artes e Comunicação, Universidade Estadual Paulista. Bauru, 2003. Disponível em: <https://repositorio.unesp.br/handle/11449/97020>. Acesso em: 23 set. 2018.

MOTA, M. A tecelã. 1956. Disponível em: < http://renemendes.com.br/blog/arte-dotrabalho/a-tecela-mauro-mota-1911-1984/>. Acesso em: 10 abr. 2019.

NOGUEIRA, L. S. de C. et al. Consumo simbólico e identidade da marca: um estudo de caso sobre a nova estratégia de produto da havaianas. In: Simpósio de Excelência em Gestão e Tecnologia - SEGeT, 11 out. 2014, Rio de Janeiro. Anais eletrônicos.... Disponível em: <https://www.aedb.br/seget/arquivos/artigos14/220434.pdf>. Acesso em: 04 out. 2019.

NUNES, L. D. Consumo de valores simbólicos: design e artesanato. In: COLÓQUIO DE MODA, 7., 2011, Maringá, PR. Anais eletrônicos... Maringá: [s.n.], 2011. Disponível em: <http://www.coloquiomoda.com.br/anais/Coloquio\%20de\%20Moda\%20-\%202011/ GT02/Comunicacao-Oral/CO_89557Consumo_de_Valores_Simbolicos_Design_e_ Artesanato_.pdf >. Acesso em: 22 ago. 2018.

PEZZOLO, D. B. Tecidos: história, tramas, tipos e usos. 2 ed. São Paulo: SENAC, 2009. $328 \mathrm{p}$.

PICHLER, R. F.; MELLO, Carolina I. de. O design e a valorização da identidade local. Design e Tecnologia, [S.I.], v. 2, n. 04, p. 1-9, dez. 2012. Disponível em: <https://www.ufrgs.br/det/index.php/det/article/view/67>. Acesso em: 24 ago. 2018.

ROCHA, M. D.; QUEIROZ, M. O significado da cor na estampa do tecido popular: a chita como estudo de caso. In: COLÓQUIO DE MODA, 6., 2010, São Paulo. Anais eletrônicos.... São Paulo: [s.n.], 2011. Disponível em: <http://www.coloquiomoda.com.br/anais/Coloquio\%20de\%20Moda\%20-\%202010/6884 
8_O_significado_da_cor_na_estampa_do_tecido_popular_-_a_.pdf >. Acesso em: 23 ago. 2018.

ROSSI, L. M. Design e artesanato no Nordeste: sustentabilidade e verbos criativos. In: OLIVEIRA, A. J.; FRANZATO, C.; DEL GAUDIO, C. (org.). Ecovisões projetuais: pesquisas em design e sustentabilidade no Brasil. Rio de Janeiro: Bluncher, 2015. p. 243 $-260$.

SILVEIRA, M. I. S. C. A tecelagem manual e o design têxtil: um diálogo entre o artesanal e o industrial. In: COLÓQUIO DE MODA, 9, 2013, Fortaleza. Anais eletrônicos... Fortaleza: [s.n.], 2013. Disponível em: <http://www.coloquiomoda.com.br/anais/Coloquio\%20de\%20Moda\%20-\%202013/COM UNICACAO-ORAL/EIXO-6-PROCESSOS-PRODUTIVOS_COMUNICACAO-ORAL/A-tecelagem -manual-e-o-design-textil-um-dialogo-entre-o-artesanal-e-o-industrial.pdf>. Acesso em: 22 ago. 2018.

TEX BRASIL - Programa de internacionalização da indústria têxtil e de moda $<$ http://texbrasil.com.br/pt/imprensa/dados-da-industria-textil-e-de-confeccao-em-201 5>. Acesso em: 28 set. 2020.

VAINSENCHER, S. A. Artesanato do Nordeste do Brasil. Pesquisa Escolar Online Fundação Joaquim Nabuco, Recife, 2007. Disponível em: $<$ http://basilio.fundaj.gov.br/pesquisaescolar/index.php?option=com_content\&view=arti cle\&id=326\&Itemid=1 (Acesso $>$. Acesso em: 29 set. 2018.

ZÉ DO NORTE. Mulher rendeira. (Letra tradicional/Adaptação). 1953. Disponível em: <https://genius.com/Ze-do-norte-mulher-rendeira-lyrics>. Acesso em: 19 out. 2019.

\footnotetext{
i Mestranda pelo Programa Associado de Pós-Graduação em Artes Visuais (UFPB/UFPE). Designer de moda formada pela Escola de Belas Artes da Universidade Federal de Minas Gerais (EBA-UFMG); Pesquisadora no grupo de pesquisa STUDIOLO - Ornamento, Arte, Tecido e Memória (EBA-UFMG), cadastrado no CNPq.

ii Professora Doutora do Curso de Design de Moda da Escola de Belas Artes da Universidade Federal de Minas Gerais (EBA-UFMG); Conservadora e restauradora de bens culturais móveis (CECOR-EBA-UFMG); Conservadora e Restauradora têxtil pelo L'Istituto per l'Arte e il Restauro do Palazzo Spinelli/Itália; Líder do grupo de pesquisa cadastrado no CNPq "STUDIOLO" (UFMG) e membro do CIETA/Lyon.
}

Como citar esse artigo:

SANTANA, Cássia Cristina Dominguez; COPPOLA, Soraya Aparecida Alvares. Moda artesanal: explorando uma cultura regional brasileira por técnicas e saberes tradicionais.

Revista Digital do LAV, Santa Maria: UFSM, v. 14, n. 1, p. 47-72, jan./abr. 2021. 